\title{
Strategic on Management Scientific Publication of Student Journal in Higher Education (a Case Study)
}

\author{
Muhammad, QOMARUDDIN \\ Master of Art in Higher Education, Faculty of Administrative Science, Brawijaya University, Indonesia \\ qomaruddin90@gmail.com \\ Ratih Nur, PRATIWI \\ Public Administrative Science, Faculty of Administrative Science, Brawijaya University, Indonesia \\ ratihnp@yahoo.com \\ Sarwono, SARWONO \\ Public Administrative Science, Faculty of Administrative Science, Brawijaya University, Indonesia \\ sarwono@ub.ac.id
}

\begin{abstract}
The current publication of scientific journals is transitioning from a print format format to an electronic format, which has a different management model than before. Publication of scientific journals is an important thing in the existence of universities. In the dissemination of science results of an education, research, and community service generated by college civitas (Students \& Lecturers) can be done with the publication of scientific journals. The purpose of this study is to determine the strategy of management publication of scientific journals that publish many articles of students at higher education. The type of this research is qualitative descriptive research. The research data were collected by indepth interview the Director of Graduate, Head of journal publishing unit, and staff of journal publishing unit. This research was conducted at the Journal Publishing Unit of Postgraduate of Brawijaya University. The managers of scientific journal publications should be continue to improve scientific publishing services and the quality of published articles, so that the management of scientific publications can compete with other electronic journals. The development of electronic journals in Indonesia has grown rapidly, within three years of electronic journal publication in Indonesia has increased sharply, from 1500 journals in 2012 to 16280 journals in 2016. This is a challenge for managers of scientific publications in Brawijaya University. The strategy in developing the management of scientific journal publications of students is to hold training activities of scientific journal writing for students to be able to provide the availability of quality articles. Benchmarking activities and management training for journal editing teams to maintain quality management and scientific journal publications. In addition, it is necessary to improve the reputation of scientific journals by paying attention to the Impact Factor; Index Journal, Ranking Journal, h-index, Number of Cites, \& Percentage of Rejection Rates in managed journals.
\end{abstract}

Keywords: Electronic Journal, Management Strategy, Student Journal

JEL Classification: I21, 123. 


\section{Introduction}

Scientific Publication is a forum for researchers, lecturers, and students to convey the scientific ideas of research and other academic studies, scientific publications can be either journals articles derived from the thesis, theses or dissertations, as well as the results of experience in seminar activities. Scientific publications are currently undergoing changes, emerging as a result of the transition from print publishing format to electronic publishing format, which has a different management model to the previous pattern. The current general trend, access to scientific journals electronically provided openly. This means more and more scholarly publications can be accessed free of charge via the internet, whether provided by the publisher of the journal or provided by the journal article writers themselves. The obligation of scholarly publication in the current journal is an inevitable activity, with the graduation rules Bachelor should publish a national journal, the Master publishes a nationally accredited journal and the Doctor publishes reputable international journals, in addition to lecturer rankings require publications of respected national and international journals. This is in accordance with the Director General of Higher Education Letter No. 152/E/T/2012: About Compulsory Scientific Publication For Bachelor / Master / Doctor explained that every college graduate should publish a scientific work, both national journals, accredited national journals, as well as reputable international journals.

Any organization of both business and non-business organizations must have a purpose. In achieving this goal, the organization needs a strategy. The strategy includes determining the objectives created by the management of the company that is expected to ensure the preservation of the company's competitive advantage (Solihin, 2012). Strategy formulation involves the determination of short-term, medium- and long-term goals to guide them in achieving goals. With this step, organizations can focus on the organization's goals. The strategic management of innovation has become a central topic within the strategic management field (e.g., Herrmann 2005; Nag et al. 2007). Developments in the innovationrelated literature over the last two decades and diverse observations by senior scholars consistently indicate that the literature on the strategic management of innovation currently exhibits many inconsistencies, competing theoretical predictions, and persisting knowledge gaps and that many questions pertaining to the strategic management of innovation are still little understood (Keupp et al. 2012). 
For people and their organizations it is not much different, since strategy also regards the quest for survival. Naturally, our perception of what is a barrier and what is an opportunity will differ according to our cognitive nature and the goals we establish to direct our life (Jofre, 2011). Common problems encountered are technical problems an insufficient number of articles, the operation of open journal system, and several other factors. These issues need to be taken care of and followed up with some concrete actions, so it is hoped that the problem will be solved and postgraduate unit services can be improved, both in the quality of articles, human resources, and information technology that support the success of the service. Based on the description above with some of the problems faced by the agency management journals to go to reputable journals, it is necessary to conduct research on Strategy of Management Scientific Publications as a means of finding strategies to be developed by the agency management of journals in publishing scientific journals. The results of this study are expected to help provide input development plan on scientific publication unit, especially in Postgraduate, generally in Brawijaya University.

\section{Method}

Method of administrative research can be interpreted as a scientific way to obtain valid data for the purpose can be found, proven and developed a certain knowledge so that in turn can be used to understand, solve, and anticipate problems in the field of administration (Sugiyono, 2006). The type of research in this research is descriptive qualitative research. This type of research intends to explain a phenomenon that exists in the field in a natural way or without giving behavior to the object of research. Qualitative descriptive research is a study that aims to describe, summarize the various conditions, various situations or phenomena of social reality that exist in the community that became the object of research and attempt to attract the reality of the surface as a characteristic, character, nature, model, or picture of the condition, situation or certain phenomena (Bungin, 2007).

This research does not intend to test the theory but attempt to dig as much as possible and as much as possible data in the field to get a picture of "Strategic Management on Scientific Publication of Electronic Journal in Graduate School, Brawijaya University". The data obtained are then used to construct or develop theories, departing from the different social realities of one individual to another, the reality photographed according to locus and focus. 
A clear and steady focus setting will make it easier for researchers to make informed decisions about what data to use and unnecessary data (Moleong, 2012). Data analysis in this research use scenario planning analysis model with tool scenario planning method that is TAIDA. A scenario planning is an alternative to running a plan. Scenario planning is also a picture of the future. According to Schwartz (Lindgren 2003), scenario planning is a tool or step to convey a perception of the picture of possible possibilities in the future.

Figure 1. An overview of the TAIDA process

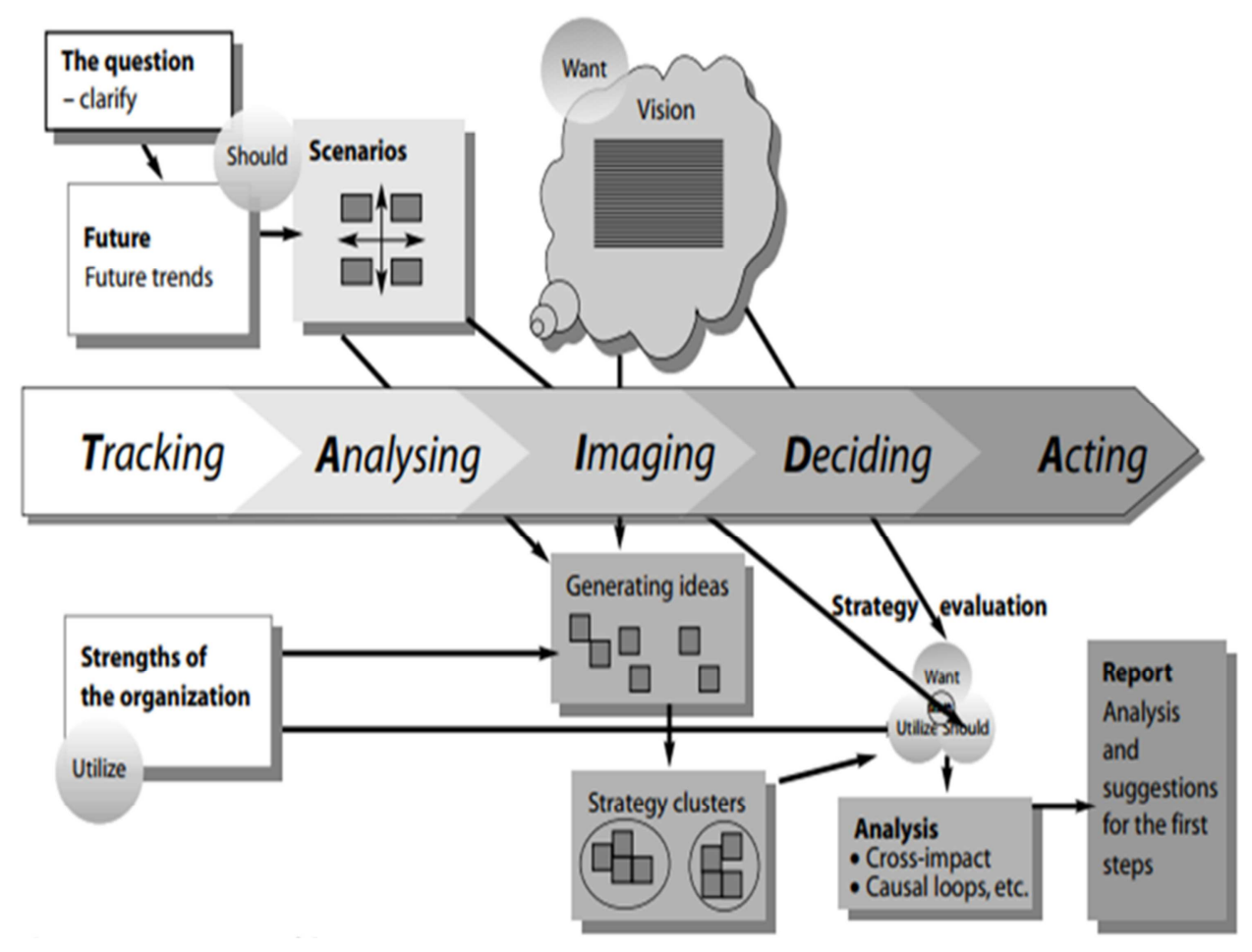

Source: Lindgren, 2003.

\section{Results and Discussion}

Each organization has a unique purpose and reason for its existence. This uniqueness should be reflected in the vision and mission of the organization. 
Vision is often seen as the first step of strategic planning, even preceding the mission statement. The vision statement is a single sentence. The vision statement is an ideally defined corporate desire that determines the direction or future state (David, 2009). This vision will guide the mobilization of corporate resources to achieve the goal. The vision created has a very close relationship with the mission, in the sense that the strategic direction stated in the vision is still within the scope of the business run by the organization. A clear vision will be the foundation for the development of a comprehensive business organization direction.

The vision that has been created will be outlined in the mission of the organization. The mission is a statement of purpose that clearly distinguishes one business from other similar companies (David, 2009). Decreasing vision to mission reflects the expected goals. This mission provides an overview of the journey from the starting point towards the point of attainment as expected. In implementing the process of change from the starting point to the goal required a systematic strategic approach and rational and objective and structured. The Graduate Vision of Brawijaya University is becoming the center for the development of multidisciplinary master and doctoral programs of international standard, through the process of education, research and community service. Based on that vision, the multidisciplinary Graduate missions are among the following:

1. Developing a multidisciplinary study program in accordance with the needs of community development and the development of Science and Technology;

2. develop and disseminate science and technology through a multidisciplinary approach and seek its application to improve people's lives and enrich national culture;

3. conducting quality assurance process for master and doctoral programs effectively and efficiently, so as to meet international standards.

In advanced organizational levels, humans do formalize strategies as a function to direct and focus their efforts. In a business organization (a firm), such efforts will focus on creating value for profit and guiding the organization towards future. In this context, the environment is a market with limited resources and therefore in which competition exists. This environment might be more or less stable, but it is in constant change. Firms will struggle to adapt to 
avoid being selected-off. Strategy in here becomes a systemic and rational act, a process that can be managed in order to successfully attain the goals of the firm (Jofre, 2011). The organization stands to achieve goals, goals are the end result to be achieved by the company within a certain time and declared quantitatively (Solihin, 2012). Objectives have significance for organizations because they state direction, assist evaluation, create synergies, explain priorities focusing coordination, provide a foundation for management activities (David, 2012). A good end goal must be manicured, specific, in accordance with vision and mission, realistic, and timely. In accordance with the vision and mission, the purpose of Graduate Multidisciplinary is as follows:

1. Standardize the quality assurance process for master and doctoral programs, and evaluate their implementation;

2. developing multidisciplinary masters and doctoral programs relevant to real development issues faced by society and development and science and technology;

3. undertake quality education in interdisciplinary master and doctor programs to address development challenges faced by society and development and science and technology;

4. publish the results of research that support the development of science and technology and used to answer the problems faced by society, nation and the Unitary State of the Republic of Indonesia;

5. establishing networking and synergistic cooperation with internal and external stakeholders in the framework of improving the quality of multidisciplinary graduate education in Brawijaya University.

The Postgraduate Mission on the second point is mentioned about the dissemination of science and technology through a multidisciplinary approach and strives for its application to improve the standard of living of the people and enrich the national culture. This is supported by the 4th objective of postgraduate which is to publish research results that support the development of science and technology and used to answer the problems faced by the people, the nation and the Unitary State of the Republic of Indonesia. The dissemination and publication of the research results are the basis for the establishment of the Publishing Journal Agency unit in Postgraduate UB. In accordance with SOTK-PerRector-No-20-Year-2016 mentioned that the function of Journal Publishing Agency is a technical implementation element in the field of journal publishing 
and publication of scientific work of lecturers and students. So the task of Journal Publishing Unit is:

1. organize education and training in the preparation of scientific publications;

2. collect and select the scientific work of lecturers and students for the purpose of publication;

3. conducting periodical publications of scientific work of lecturers and students in the form of other journals and publications; and

4. report periodically to the Dean.

Based on the results of this study it can be seen that the Publishing Journal Unit currently manages 7 scientific publications. 4 of the 7 managed journals have been indexed by Index Copernicus and DOAJ. The ranking of Brawijaya University based on the number of article journals indexed by Scopus is positioned in 9 out of 10 State Institutions/Universities that publishes journals in Indonesia. While based on data of SINTA National Index, the position of Brawijaya University is positioned in 9 with a total score of 4,094 under Indonesia University of Education which has a score of 5,583.

Strategic quality planning includes vision, mission, and values of the firms. They are formed by taking into account the quality concept. With effective strategic quality planning efforts employees are taken as an input in developing the vision, mission, strategies, and objectives (Sadikoglu, 2014). This facilitates acceptance and support of strategic quality plans by the employees. Successful strategic quality planning efforts also take into account the possible side effects of the plan to the environment prior to the production. This will manifest and improve social responsibility of the firm.

The management of scientific publications is not an easy task because it requires more focus to be able to develop periodical publications into credible publications (national accredited and reputable international indexed). In general, there are three issues faced by the managers of scientific publications, among others: (1) availability of quality articles; (2) management of nonstandard scientific publications as requested by accreditation and indexing agencies; and (3) the sustainability of the management of scientific publications. Motivation to conduct research has not been matched by moral responsibility as a researcher to disseminate the results of his research is very useful for the wider community both for practical interests and theoretical development. With the 
publication of research results in periodical scientific publications, researchers will get a lot of input and at the same time the opportunity to further develop research in the future.

Figure 2. Analysis Data of strategic management of scientific publications

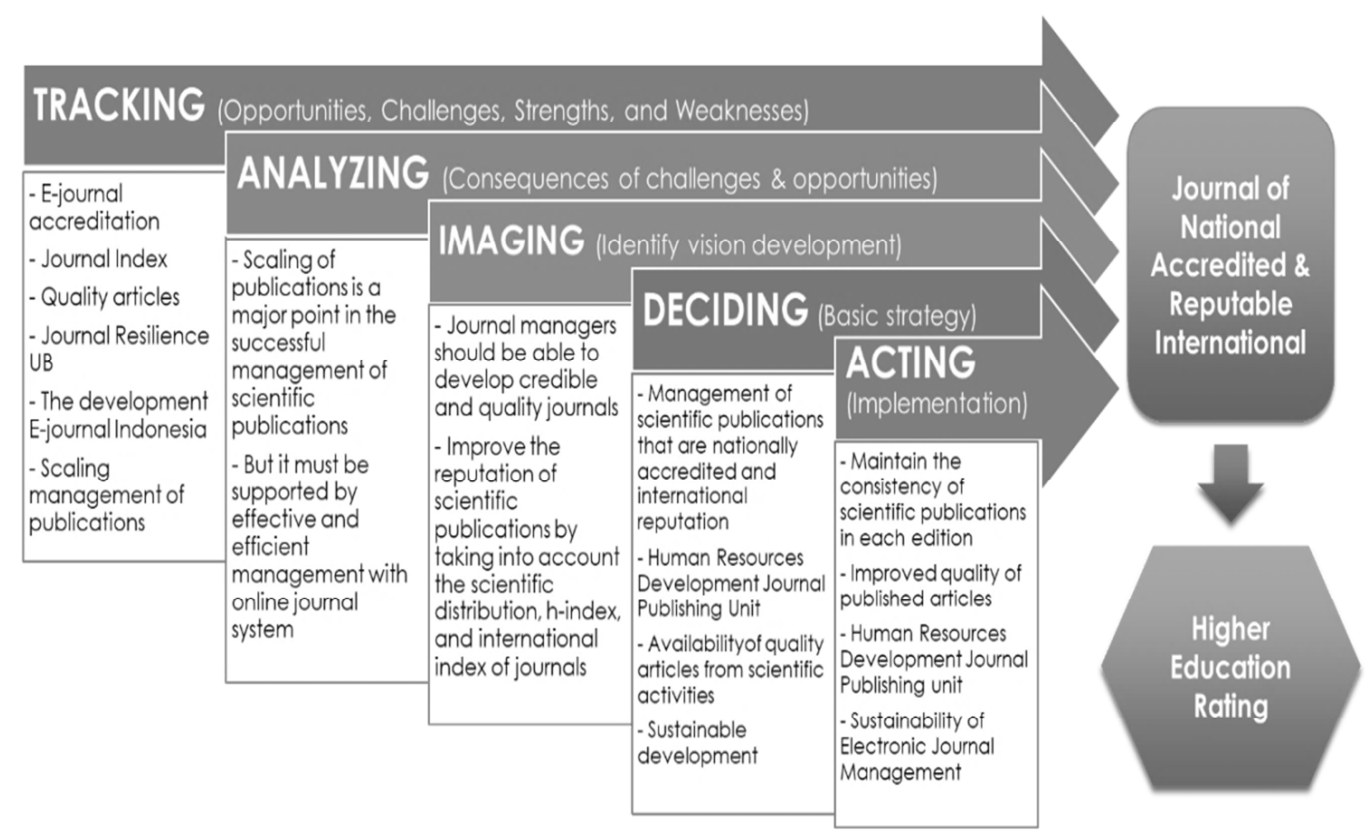

Source: Sadikoglu, 2014

Improving the quality of journal articles to better be done with various things. For example, with the activities of writing journal articles held by the unit publishing journal with the intended participants are students who will write a Journal for graduation terms. The team of editors and journal reviewers also play an important role in improving the quality of journal articles published. This is in accordance with the submitted M. Firdaus as chairman of the journal publishing agency such as follows:

Perform benchmarking and management workshops and article writing to improve the quality of articles. The quality of the article is inseparable from the role and consistency of the editorial team in managing the journal and its knowledge and understanding in the management of accredited or 
internationally reputable journals (Interview on 14 June 2017).

The results of this study indicate the need for benchmarking and workshop activities for journal editing teams, it is necessary to evaluate each published issue of the journal. This activity will assist in maintaining the quality of published articles, in addition to helping maintain the consistency of periodical publications, in accordance with what M. Firdaus conveys as follows:

Benchmarking and workshop work for the journal editor team is at least done after one publishing number so that the editor team can evaluate the performance of what has been done now in maintaining and knowing the quality of articles published in the journals it manages (Interview on 14 June 2017).

Quality articles will be able to influence the national accreditation process or submit a better-earned index of journals. The quality and quantity of scientific articles are indispensable for improving the quality of publications. To maintain the availability of articles in journal publications it is necessary to do article crawl through scientific seminar activities aimed at students and lecturers around us, this is in accordance with the statement of Abdul Hakim as Postgraduate Director as follows:

The management of scientific publications should consider the quality aspects of published articles. The better the quality of published articles will affect the value of national accolades of journal publishing institutions. With seminar or journal training activities it is expected that the availability of quality articles for journals can be fulfilled (Interview on May 31, 2017).

In the era of globalization, public organizations (government) and business organizations are required to develop excellent service. There are several important reasons for the need for excellent service management. First, in the field of governance requires the existence of effective, efficient, and economical services in accordance with the interests of society (citizen). Secondly, in the field of business, there is an effort to increase the attractiveness of consumers (customers) to select the desired product. Excellent service is one of the benchmarks of organizational performance, both government and private. Therefore, the demand for quality services must be met by government or private organizations. Management of online scientific publications directly will assist in providing services effectively and efficiently in journal publishing. In 
addition, it is now mandatory for all journals managers to publish and manage their publications online. This is in accordance with the terms for the submission of online journal accreditation and the filing of a reputable index. Scientific online publications will accelerate in the delivery, editing, publishing, appearance, scaling, and dissemination of scientific journals.

Strategy refers to either the plan made or the action in effort to help an organization fulfill its intended propose and strategy refers to propose the organization strives to achieve these strategy posed by typical businesses can be very broad (vision and mission) or more focused (goals and objectives)" (Alex Miller (1996) in Purwanto, 2012). The recommended strategy alternative in the management of scientific publications is to improve the capability of human resources (Team Editor, Reviewer, and Secretariat) in the management of electronic scientific publication (e-journal). With the management of scientific publications electronically it will assist in accelerating the preparation of the management of credible electronic publications (accredited national and international indexed). In managing scientific publications electronically human resources are required to have competence in the field of Information technology to support the submission of reputable indices, management of electronic publications in accordance with national accreditation standards, and can follow the updated information management electronic scientific publications in the World.

Human Resources is a very important factor for every business, as well as for the government to be able to carry out its function properly. Many definitions can be used to define human resources. According to Susilo (2002), Human resources are the main supporting pillar as well as drive the organization in an effort to realize the vision and mission and goals. "Human resources must be defined not by what human resources do, but what human resources produce," as David Ulrich (Mathis and Jackson, 2002) suggests. Therefore, Human Resources is an important factor for every business. Qualified human resources will determine the glory or failure in competition (Tambunan, 2003). The efficiency and effectiveness of the organization are strongly influenced by the procurement planning of its human resources. If the HR procurement system has not been based on the needs of the work required, then the Human Resources obtained must not be in accordance with the basic tasks and job functions required. 
The paradigm shift from printed electronic publication to electronic must be followed by the author and publisher so that the result of the work can be known and known to the society both nationally and internationally. Today's information and communication technology bring major changes to the management system of scientific publication publications in Indonesia and the World. With the e-journal system the process of indexing and the scientific impact or citation of a journal article will be known quickly, so the benefits of a scientific paper can be known immediately. The e-journal system is expected to cut the time of scientific publication online faster than printed publications. Increased accessibility of electronic journal pages can be monitored by increasing number of unique visitors to the page over time which can be interpreted as a number of circulation, so visibility and scientific impact on search engines such as Google Scholar are increasing. This is in accordance with what is conveyed by Abdul Hakim as follows:

The management of current scientific publications must be with the online system. This is because with the online system the published journal articles will be easier to disseminate, in which the dissemination of scientific articles either offline or online is an important point in the sustainability of the management of scientific publications affecting the accreditation value of scientific publications "(Interview on May 31, 2017).

Obviously, a great deal of strategic thinking must go into developing a strategic plan and, once developed, a great deal of strategic management is required to bring its aims to fruition. But, as several authors have pointed out, the objective is indeed to think and manage strategically, not to blindly engage in strategic planning for the sake of strategic planning. However, when it comes to specifying the substance of the distinctions among strategic thinking, strategic planning and strategic management, all authors are noticeably reticent. So, we will take those distinctions as amounting to a well-meant caution against confusing the form of strategic planning with its substance (Nickols, 2016).

Alternative strategy in supporting the activities of Scientific Publication Management Sustainability by enhancing the reputation of scientific journals by paying attention to the Impact Factor; Scimago Journal, Index Journal, Ranking, h-index, i10-index, Number of Cites, Percentage of Rejection Rates in managed journals. Rankings of strategy journals are important for authors, readers, and promotion and tenure committees. It is prove useful for authors in choosing 
where to submit their papers, readers in deciding what to read, and tenure and promotion committees in evaluating academic publications (Azar, 2008).

Figure 3. Step of strategy for the management of scientific publications
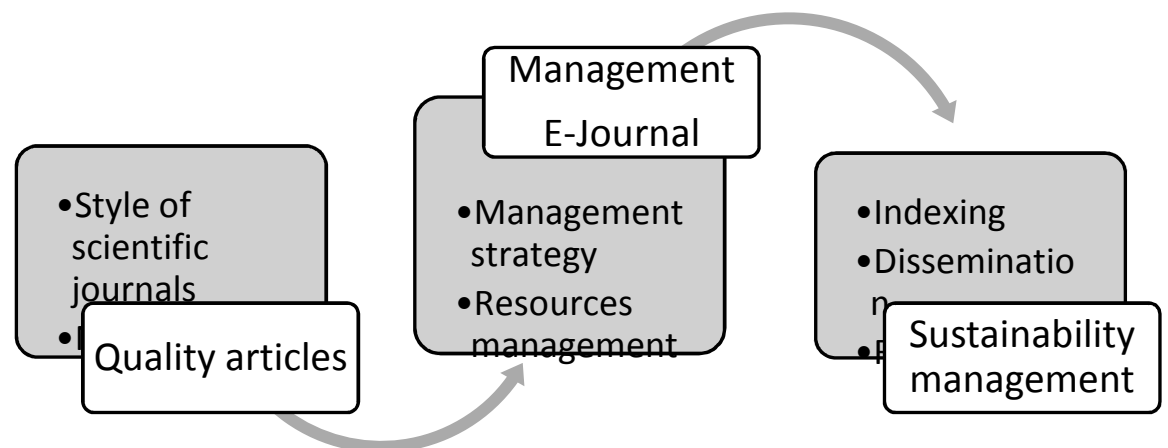

Source: the author

\section{Conclusions}

Alternative strategies for maintaining the availability of quality manuscripts for journal issues that are managed include: (1) held training activities of scientific journal writing for students and lecturers, such activities are important to be able to provide availability of quality articles because it is in accordance with the rules of scientific journals. (2) Conducting benchmarking activities or workshops for the journal editor team for management training of journal publishing \& evaluation of each published issue of the journal. This is because the quality and quality of the article cannot be separated from the role and consistency of the editor and reviewer team in managing the journal. So the team of editors and reviewers should have more knowledge and experience in the management of accredited or internationally reputed journals. (3) English checks for every new entry, and plagiarism checks for newly signed articles and articles to be published online.

The alternative strategies suggested by researchers in the management of scientific publications is to improve the capabilities of human resources (Editor Team, Reviewer, and Secretariat) in the management of electronic scientific publication (online). With the management of scientific publications electronically it will assist in accelerating the preparation of the management of 
credible electronic publications (accredited and indexed with reputable). In managing electronic scientific publications, human resources are required to have competencies in the field of Information technology to support the submission of reputable indices, management of electronic publications in accordance with national accreditation standards, and to keep up with the latest information on electronic scientific publication management in the World.

An alternative strategy in supporting the activities of Scientific Publication Management Sustainability, among others: (1) Maintaining the quality and quantity of every article published by scientific journals and disseminating published scientific journals. (2) Improving the reputation of scientific journals by paying attention to the Impact Factor; Scimago Journal, Index Journal, Ranking, h-index, i10-index, Number of Cites, Percentage of Rejection Rates in managed journals.

References

[1] Azar, Ofer H. David M. Brock. (2008). A Citation-Based Ranking of Strategic Management Journals. Journal of Economics \& Management Strategy, Volume 17, Number 3, Fall 2008, 781-802

[2] Bungin, Burhan H.M, (2007). Penelitian Kualitatif: Komunikasi, Ekonomi, Kebijakan Publik, dan IImu social. Kencana Prenama Media Group, Jakarta

[3] David, Fred R. (2009). Manajemen Strategis, Salemba Empat. Rangkuti, Jakarta

[4] Dirjen Dikti. (2012). Publikasi Karya IImiah No. 152/E/T/2012. Ministry of National Education, Jakarta

[5] Hermann, P. (2005). Evolution of Strategic Management: The Need for New Dominant Designs. International Journal of Management Reviews, 7, pp. 111-130.

[6] Jofre, S. (2011). Strategic Management: The Theory and Practice of Strategy in (Business) Organizations. KGS. Lyngby: DTU Management. (DTU Management 2011; No. 1).

[7] Keupp, Marcus Matthias. Maximilian Palmié. Oliver Gassmann. (2012). The Strategic Management of Innovation: A Systematic Review and Paths for Future Research. International Journal of Management Reviews, 14(4): 367-390

[8] Lindgren, Mats., Hans Bandhold. (2003). Scenario Planning: the Link Between Future and Strategy. Palgrave MacMillan, New York

[9] Moleong, Lexy J. (2012). Qualitative Research Methodology. Remaja Rosdakarya, Bandung

[10] Nag, R., Hambrick, D.C. and Chen, M. (2007). What is strategic management, really? Inductive derivation of a consensus definition of the field. Strategic Management Journal, 28, pp. 935-955.

[11] Nickols ,Fred. (2016). Strategy, Strategic Management, Strategic Planning and Strategic Thinking. Distance Consulting. Mount Vernon, $\mathrm{OH} 43050$

[12] Purwanto, Agus Erwan. (2012). Implementasi Kebijakan Publik Konsep dan Aplikasinya di Indonesia. Gava Media, Yogyakarta 
[13] Sadikoglu, Esin. Hilal, Olcay. (2014). The Effects of Total Quality Management Practices on Performance and the Reasons of and the Barriers to TQM Practices in Turkey. Hindawi Publishing Corporation. Advances in Decision Sciences. Volume 2014, Article ID 537605, 17 pages. http://dx.doi.org/10.1155/2014/537605

[14] Solihin, Ismail. (2012). Manajemen Strategik. Erlangga, Jakarta

[15] Sugiyono. (2006). Metode Penlitian Administrasi Bisnis. Alfabeta, Bandung

[16] Susilo, Martoyo. (2002). Manajemen Sumber Daya Manusia. Edisi Kedelapan. BPFE. Yogyakarta 